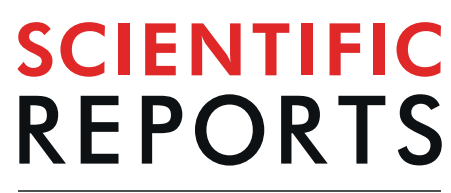

natureresearch

Check for updates

\title{
OPEN Establishment of patient-derived xenografts from patients with gastrointestinal stromal tumors: analysis of clinicopathological characteristics related to engraftment success
}

\author{
Young-Soon $\mathrm{Na}^{1,4}$, Min-Hee Ryu ${ }^{2,4}$, Young Soo Park ${ }^{3}$, Chae-Won Lee ${ }^{1}$, Ju-Kyung Lee ${ }^{1}$, \\ Yangsoon Park ${ }^{3}$, Jung Min Park ${ }^{1}$, Jungeun Ma ${ }^{2} \&$ Yoon-Koo Kang ${ }^{2}$
}

Patient-derived xenografts (PDXs) can represent the heterogeneity and histological characteristics of tumors and are thus useful for testing the efficacy of anti-cancer drugs; however, PDXs are difficult to generate, especially for gastrointestinal stromal tumor (GIST). We analyzed the clinicopathologic

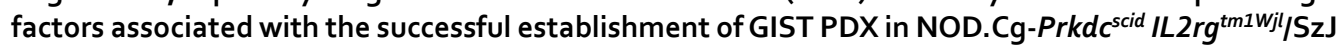
mice. We used 185 GIST tumor fragments from patients who underwent surgical resection prior to $(n=66 ; 35.7 \%)$ and after treatment $(n=119 ; 64.3 \%)$ with tyrosine kinase inhibitors. The overall success rate of PDX establishment was 17\%; in univariate analysis, engraftment success was associated with after TKI treatment, larger tumor size, higher mitotic count, higher Ki-67 index, higher cellularity, presence of tumor necrosis, primary mutations in KIT exon 11, and originating from metastatic lesions. In multivariate analysis, higher Ki-67 index, after TKI treatment, and larger tumor size were independent factors for engraftment success. Immunohistochemistry in representative samples further corroborated the above results. These results will be useful in the establishment of PDX models from GISTs.

In the development of anti-cancer drugs, drug responses are tested on cell lines or xenografts. However, as these models cannot accurately represent the patient's tumor status, they cannot reflect drug efficacy as well ${ }^{1,2}$. Therefore, it is necessary to develop a system in which the tumor status of a patient is well-reflected to develop efficient and specific anti-cancer agents and to study the biological characteristics of each cancer type ${ }^{3,4}$. For this purpose, patient-derived xenograft (PDX) models are widely used.

Even though PDXs are time-consuming and costly for preclinical research, they are more accurate than cell lines and cell line xenografts in representing tumor heterogeneity, histological characteristics of the original tumor and stromal compartment at the early stage ${ }^{5}$. PDXs also retain many molecular features of the original patient tumors, and the clinical response concordance is better in PDXs than in cell lines and cell line xenografts $^{2,6}$. Therefore, PDX models are helpful in cancer studies ${ }^{6,7}$. PDXs have been established in various tumor types with varying success rates, ranging from $95 \%$ in prostate cancer to $9 \%$ in renal cell carcinoma ${ }^{1,2}$. For soft tissue sarcomas, the success rates of PDXs have been reported to be 37.8 to $70.9 \%{ }^{8}$. However, only a few gastrointestinal stromal tumor (GIST) PDX models have been reported to date.

GIST is the most common mesenchymal tumor of the gastrointestinal tract, and is characterized by mutations in the KIT or platelet-derived growth factor receptor alpha (PDGFRa) genes. Accordingly, tyrosine kinase

\footnotetext{
${ }^{1}$ Asan Institute for Life Sciences, Asan Medical Center, University of Ulsan College of Medicine, Seoul, Korea. ${ }^{2}$ Department of Oncology, Asan Medical Center, University of Ulsan College of Medicine, Seoul, Korea. ${ }^{3}$ Department of Pathology, Asan Medical Center, University of Ulsan College of Medicine, Seoul, Korea. ${ }^{4}$ These author contributed equally:Young-Soon Na and Min-Hee Ryu. ${ }^{\bowtie e}$-mail: ykkang@amc.seoul.kr
} 
inhibitors (TKIs) targeting these active mutations (i.e., imatinib, sunitinib, and regorafenib) have shown promising results and are therefore approved for the treatment of GIST through clinical trials. Unfortunately, most of the patients eventually show disease progression even after receiving these drugs ${ }^{9,10}$.

The initial report on the GIST PDX models with mutations of KIT exon 11 was published by Huynh et al. ${ }^{11}$. UZLX-GIST9 harboring both primary and secondary mutations in KIT exons 11 and 17 was established from a metastatic lesion that showed clinical progression after treatment with imatinib, sunitinib, and regorafenib. GIST PDX models harboring primary mutation alone in either KIT exon 9 or exon 11 were also reported ${ }^{12-16}$. We have previously reported the establishment of 3 separate GIST PDX models - GIST-RX1 (mutations in KIT exons 11, 17, and PTEN from a patient with resistance to imatinib, sunitinib, and sorafenib), GIST-RX2 (mutations in KIT exons 11 and 14 from a patient with resistance to imatinib), and GIST-RX4 (mutations in KIT exons 9 and 17 from a patient with resistance to imatinib and sunitinib) ${ }^{17}$. Some GIST PDXs are commercially available, but they do not have various KIT mutations.

Previous studies have shown that the successful establishment of PDXs is critically influenced by factors such as characteristics of tumor tissue or the process of PDX establishment ${ }^{5,18}$. Therefore, we examined the clinicopathological characteristics associated with the successful establishment of GIST PDXs.

\section{Results}

Clinical characteristics of the GIST patients at tissue collection. The clinical characteristics of the 176 patients with GIST (185 samples) at tissue collection are shown in Table 1. The median age was 59 years, and the primary sites were mostly the stomach (47.0\%) and small bowels (47.6\%). A total of 66 (35.7\%) samples were from treatment-naive patients, 119 (64.3\%) were from patients after TKI treatment at the time of resection. The largest tumor size in the majority of samples was $\leq 50 \mathrm{~mm}(\mathrm{n}=93 ; 50.3 \%)$. Primary mutations were mostly located in KIT exon $11(62.7 \%)$ and exon 9 (14.1\%), with a minor portion of samples harboring primary mutations in KIT exon 17 or PDGFRA exon 18. Approximately one-third (35.7\%) of the samples were from patients who had localized resectable disease and had not received TKI therapy at the time of tissue collection, while the other two-thirds $(64.3 \%)$ were from patients who had received TKI therapy. The median treatment durations with imatinib, sunitinib, and regorafenib were $34.4,11.9$, and 11.1 months, respectively.

Clinicopathological characteristics of patients with successful PDX establishment. We successfully established 31 GIST PDX models from 185 samples (16.8\%), including the previously reported 3 PDX models ${ }^{17}$. The clinicopathological characteristics of the cases with successful PDX establishment are summarized in Table 2. Four PDX models were established from localized tumor samples and 27 were established from metastatic tumor samples. Thirty PDX models were established from GIST lesions resistant to imatinib, sunitinib, and/ or regorafenib, and only one was established from a GIST patient prior to TKI treatment. The clinicopathological characteristics of the cases with unestablished PDX are summarized in Supplementary Table S1.

There were two cases from whom distinct PDXs had been established at different timepoints. GIST-RX5 and GIST-RX6 were established from a patient at the time of progressive disease while receiving imatinib and sunitinib, respectively. GIST-RX17 and GIST-RX29 were established from a patient at the time of progressive disease while receiving imatinib and regorafenib, respectively. In one patient, PDX was not established when the sample was obtained during progressive disease after $800 \mathrm{mg}$ imatinib, but a later sample obtained after re-challenge with imatinib was successfully established as a PDX (GIST-RX23). In another patient, a sample obtained during sunitinib treatment was successfully established as a PDX (GIST-RX8), and a later sample obtained after re-challenge with imatinib after progression is being monitored for tumor formation in F1. Nine samples from four patients were not established as PDX even when the samples were obtained after different responses to drugs.

Clinicopathological characteristics related to engraftment success. We examined the clinicopathological characteristics associated with the successful establishment of PDX (Table 3). In univariate analysis, factors such as age, sex, primary tumor sites, and cell types did not show a significant association with PDX engraftment success rate. Conversely, the majority of successful samples $(96.8 \%, 30 / 31)$ were from patients after TKI treatment $(p=0.003)$. In terms of largest tumor size, the success rate was the highest in the $>100 \mathrm{~mm}$ group $(37.5 \%)$ and lowest in the $\leq 50 \mathrm{~mm}$ group $(6.5 \%, p<0.001)$. As for mitotic count, $58(31.4 \%)$ and $127(68.6 \%)$ samples had mitotic counts of $\leq 5 / 50$ high power fields (HPFs) and $>5 / 50 \mathrm{HPFs}$; importantly, the $>5 / 50 \mathrm{HPF}$ group had a significantly higher proportion of successful engraftment $(23.6 \% \mathrm{vs} .1 .7 \%, p<0.001)$. The success rate also significantly differed between samples with necrosis and those without $(26.4 \%$ vs. $8.3 \%, p=0.001)$. Samples with Ki-67 expression of $\geq 1 / 3$ had a significantly higher success rate than those $<1 / 3(42.9 \%$ vs. $5.4 \%$, $p<0.001)$. Samples with high cellularity had a higher success rate $(26.2 \%)$ than did those with low cellularity $(4.9 \%, p<0.001)$. Notably, the PDX engraftment success rate was higher in samples with primary mutations in KIT exon $11(22.4 \%)$ than in others $(8.6 \%, p=0.031)$. Lastly, samples from metastatic sites had a higher success rate than those from primary sites $(27.6 \%$ vs. $4.6 \%, p<0.001)$.

We assessed the multicollinearity of the final model by using variance inflation factors. Univariate analysis showed that factors such as after TKI treatment, largest tumor size, mitotic count, Ki-67, cellularity, necrosis, primary mutation, and tumors originating from metastatic lesions were significantly associated with the successful establishment of PDX. Among them, the following remained as significant factors for success in multivariable analysis with backward elimination: Ki-67 index of $\geq 1 / 3$ (odds ratio [OR]: 7.317, 95\% confidence interval [CI]: 2.880-20.582; $p<0.001$ ), after TKI treatment (OR: 9.437, 95\% CI: 1.730-176.100; $p=0.035$ ), and largest tumor size of >100 mm (OR: 4.197, 95\% CI: 1.285-14.835; $p=0.020)$ and 50-100 mm (OR: 2.855, 95\% CI: 0.941-9.464; $p=0.071$ ) (overall $p=0.057$ ). We analyzed the success rate according to the number of three factors related to 


\begin{tabular}{|c|c|}
\hline Characteristics & No. (\%) \\
\hline \multicolumn{2}{|l|}{ Age (year) } \\
\hline median (range) & $59(28-88)$ \\
\hline$\leq 59$ & $93(50.3)$ \\
\hline$>59$ & $92(49.7)$ \\
\hline \multicolumn{2}{|l|}{ Sex } \\
\hline male & $97(52.4)$ \\
\hline female & $88(47.6)$ \\
\hline \multicolumn{2}{|l|}{ Primary site } \\
\hline stomach & $87(47.0)$ \\
\hline small bowel & $88(47.6)$ \\
\hline large intestine & $8(4.3)$ \\
\hline others & $2(1.1)$ \\
\hline \multicolumn{2}{|l|}{ Disease status } \\
\hline before TKI & $66(35.7)$ \\
\hline after TKI & $119(64.3)$ \\
\hline \multicolumn{2}{|l|}{ Largest tumor size (mm) } \\
\hline$\leq 50$ & $93(50.3)$ \\
\hline $50-100$ & $60(32.4)$ \\
\hline$>100$ & $32(17.3)$ \\
\hline \multicolumn{2}{|l|}{ aprimary mutation } \\
\hline KIT exon 9 & $26(14.1)$ \\
\hline KIT exon 11 & $116(62.7)$ \\
\hline Others & $12(6.5)$ \\
\hline Wild type & $20(10.8)$ \\
\hline $\mathrm{NE}$ & $11(5.9)$ \\
\hline \multicolumn{2}{|l|}{ Resection site for PDX } \\
\hline primary & $87(47.0)$ \\
\hline metastasis & $98(53.0)$ \\
\hline \multicolumn{2}{|l|}{ Drug exposure } \\
\hline No & $66(35.7)$ \\
\hline Imatinib alone & $84(45.4)$ \\
\hline Imatinib and Sunitinib & $25(13.5)$ \\
\hline Imatinib, Sunitinib, and Regorafenib & $10(5.4)$ \\
\hline \multicolumn{2}{|l|}{ Duration of TKI (months) } \\
\hline Imatinib, median (range) & $34.4(0.9-145.9)$ \\
\hline Sunitinib, median (range) & $11.9(0.7-58.1)$ \\
\hline Regorafenib, median (range) & $11.1(3.7-32.9)$ \\
\hline
\end{tabular}

Table 1. Clinical characteristics of the GIST patients at tissue collection. TKI: tyrosine kinase inhibitor. Wild type: non-KIT and non-PDGFR mutant. PDX: patient-derived xenograft. NE: not evaluated. ${ }^{a}$ Mutation analysis in KIT exons 9, 11, 13,14, and 17, and PDGFRa exons 12 and 18 by Sanger sequencing.

success (i.e., Ki-67 $\geq 1 / 3$, after TKI treatment, and largest tumor size [ $>50$ or $>100]$ ) as shown in Supplementary Table S2. The greater the number of factors related to success, the more we can consider these as high-engrafters.

We performed immunohistochemistry on all samples. Figure 1 shows the representative images of a successful sample (GIST-RX18) and an unsuccessful sample for PDX establishment. Compared with unsuccessful samples, successful samples had higher cellularity, higher mitotic count, and higher Ki-67 expression, indicating that these factors are indeed related to successful PDX establishment.

\section{Discussion}

We analyzed 12 clinicopathologic factors to determine the factors associated with successful PDX engraftment. Our multivariate analysis showed that the Ki-67 index was an independent factor associated with PDX engraftment success; also, after TKI treatment and the largest tumor size showed some association with PDX success as well. As previously reported, short tandem repeat (STR) analysis, histological analysis, mutation analysis, and monitoring response to TKI were performed in patients and their matched established tumors from the PDX models to validate the established PDXs ${ }^{17}$. Among the patients with GIST who develop resistance to TKIs, some cases lose KIT expression over time for yet unknown reasons. However, in our PDX models, KIT expressions were confirmed using immunohistochemistry in all patients at the time of establishment and remained evident in Western blotting in the $4^{\text {th }}-5^{\text {th }}$ passage (F4-F5) PDXs that have been investigated to date. We are currently conducting a molecular-level analysis of the established 28 models, three of which have been characterized in our 


\begin{tabular}{|c|c|c|c|c|c|c|c|c|c|c|c|c|}
\hline \multirow[b]{2}{*}{ PDX } & \multicolumn{12}{|c|}{ Patient } \\
\hline & No. & Age & Sex & $\begin{array}{l}\text { Primary } \\
\text { site }\end{array}$ & $\begin{array}{l}\text { aResection } \\
\text { site } \\
\end{array}$ & \begin{tabular}{|l|} 
Largest \\
tumor \\
size $(\mathrm{mm})$
\end{tabular} & \begin{tabular}{|l|} 
Mitotic \\
count (/50 \\
HPFs) \\
\end{tabular} & Ki-67 & Cellularity & $\begin{array}{l}\begin{array}{l}\text { Tumor } \\
\text { necrosis }\end{array} \\
\end{array}$ & \begin{tabular}{|l} 
Primary \\
mutation
\end{tabular} & \begin{tabular}{|l|l} 
bDrug \\
exposure \\
(months)
\end{tabular} \\
\hline GIST-RX1 & 1 & 67 & $\mathrm{~F}$ & $\begin{array}{l}\text { small } \\
\text { bowel }\end{array}$ & $\begin{array}{l}\text { peritoneum } \\
\text { (M) }\end{array}$ & 108 & 500 & $\geq 1 / 3$ & high & yes & $\begin{array}{l}\text { KIT } \\
\text { exon } 11\end{array}$ & $\begin{array}{l}\text { I (43) } \\
\text { S (11) } \\
\text { So (2) }\end{array}$ \\
\hline GIST-RX2 & 2 & 42 & M & stomach & \begin{tabular}{|l|} 
stomach \\
$(\mathrm{P})$
\end{tabular} & 76 & 51 & $<1 / 3$ & high & no & $\begin{array}{l}\text { KIT } \\
\text { exon } 11\end{array}$ & I (21.5) \\
\hline GIST-RX3 & 3 & 43 & M & $\begin{array}{l}\text { small } \\
\text { bowel }\end{array}$ & $\begin{array}{l}\text { peritoneum } \\
\text { (M) }\end{array}$ & 174 & 88 & $\geq 1 / 3$ & high & yes & $\begin{array}{l}\text { KIT } \\
\text { exon } 11\end{array}$ & $\begin{array}{l}\text { I (49.5) } \\
\text { S (58.1) }\end{array}$ \\
\hline GIST-RX4 & 4 & 79 & M & $\begin{array}{l}\text { small } \\
\text { bowel }\end{array}$ & $\begin{array}{l}\text { liver } \\
(\mathrm{M})\end{array}$ & 250 & 129 & $\geq 1 / 3$ & high & yes & $\begin{array}{l}\text { KIT } \\
\text { exon } 9\end{array}$ & $\begin{array}{l}\text { I (30.3) } \\
\text { S (5.6) }\end{array}$ \\
\hline GIST-RX5 & 5 & 40 & M & $\begin{array}{l}\text { small } \\
\text { bowel }\end{array}$ & $\begin{array}{l}\text { small bowel } \\
(\mathrm{P})\end{array}$ & 57 & 45 & $<1 / 3$ & high & yes & $\begin{array}{l}\text { KIT } \\
\text { exon } 11\end{array}$ & I (95.6) \\
\hline GIST-RX6 & 5 & 40 & M & $\begin{array}{l}\text { small } \\
\text { bowel }\end{array}$ & $\begin{array}{l}\text { peritoneum } \\
\text { (M) }\end{array}$ & 131 & $>150$ & $\geq 1 / 3$ & high & no & $\begin{array}{l}\text { KIT } \\
\text { exon } 11\end{array}$ & $\begin{array}{l}\mathrm{I}(101.4) \\
\mathrm{S}(0.9)\end{array}$ \\
\hline GIST-RX7 & 6 & 42 & M & others & $\begin{array}{l}\text { peritoneum } \\
(\mathrm{M})\end{array}$ & 67 & 300 & $\geq 1 / 3$ & high & yes & $\begin{array}{l}\text { KIT } \\
\text { exon } 11\end{array}$ & $\begin{array}{l}\mathrm{I}(105.3) \\
\mathrm{S}(0.7)\end{array}$ \\
\hline GIST-RX8 & 7 & 61 & M & $\begin{array}{l}\text { small } \\
\text { bowel }\end{array}$ & $\begin{array}{l}\text { peritoneum } \\
\text { (M) }\end{array}$ & 54 & 119 & $\geq 1 / 3$ & high & yes & $\begin{array}{l}\text { KIT } \\
\text { exon } 11\end{array}$ & $\begin{array}{l}\text { I (88.1) } \\
\text { S (4.6) }\end{array}$ \\
\hline GIST-RX9 & 8 & 49 & $\mathrm{~F}$ & $\begin{array}{l}\text { small } \\
\text { bowel }\end{array}$ & $\begin{array}{l}\text { liver } \\
(\mathrm{M})\end{array}$ & 136 & 140 & $\geq 1 / 3$ & high & yes & $\begin{array}{l}\text { KIT } \\
\text { exon } 11\end{array}$ & \begin{tabular}{|l|} 
I (41.6) \\
S (21) \\
R (6)
\end{tabular} \\
\hline GIST-RX10 & 9 & 60 & F & stomach & $\begin{array}{l}\text { peritoneum } \\
(\mathrm{M})\end{array}$ & 90 & 110 & $\geq 1 / 3$ & high & yes & $\begin{array}{l}\text { KIT } \\
\text { exon } 11\end{array}$ & $\begin{array}{l}\mathrm{I}(0.3) \\
\mathrm{S}(22.8)\end{array}$ \\
\hline GIST-RX11 & 10 & 50 & M & $\begin{array}{l}\text { small } \\
\text { bowel }\end{array}$ & $\begin{array}{l}\text { liver } \\
\text { (M) }\end{array}$ & 230 & 20 & $<1 / 3$ & low & yes & $\begin{array}{l}\text { KIT } \\
\text { exon } 11\end{array}$ & $\begin{array}{l}\text { I (98.6) } \\
\text { S (11.6) }\end{array}$ \\
\hline GIST-RX12 & 11 & 76 & F & stomach & $\begin{array}{l}\text { peritoneum } \\
\text { (M) }\end{array}$ & 215 & 60 & $\geq 1 / 3$ & high & yes & $\begin{array}{l}\text { KIT } \\
\text { exon } 11\end{array}$ & I (19.4) \\
\hline GIST-RX13 & 12 & 72 & F & $\begin{array}{l}\text { small } \\
\text { bowel }\end{array}$ & $\begin{array}{l}\text { peritoneum } \\
\text { (M) }\end{array}$ & 73 & 115 & $\geq 1 / 3$ & high & yes & WT & I (11.3) \\
\hline GIST-RX14 & 13 & 54 & $\mathrm{~F}$ & \begin{tabular}{|l|} 
small \\
bowel
\end{tabular} & $\begin{array}{l}\text { liver } \\
(\mathrm{M})\end{array}$ & 50 & 5 & $\geq 1 / 3$ & low & no & $\begin{array}{l}\text { KIT } \\
\text { exon } 11\end{array}$ & \begin{tabular}{|l|} 
I (34.2) \\
S (22.3) \\
\end{tabular} \\
\hline GIST-RX15 & 14 & 55 & F & stomach & $\begin{array}{l}\text { liver } \\
(\mathrm{M})\end{array}$ & 81 & 138 & $\geq 1 / 3$ & high & yes & $\begin{array}{l}\text { KIT } \\
\text { exon } 11\end{array}$ & I (33) \\
\hline GIST-RX16 & 15 & 32 & F & stomach & $\begin{array}{l}\text { liver } \\
(\mathrm{M})\end{array}$ & 110 & 22 & $\geq 1 / 3$ & high & yes & $\begin{array}{l}\text { KIT } \\
\text { exon } 11\end{array}$ & I (10.8) \\
\hline GIST-RX17 & 16 & 50 & M & $\begin{array}{l}\text { small } \\
\text { bowel }\end{array}$ & $\begin{array}{l}\text { peritoneum } \\
\text { (M) }\end{array}$ & 29 & 46 & $\geq 1 / 3$ & high & no & $\begin{array}{l}\text { KIT } \\
\text { exon } 11\end{array}$ & I (34.6) \\
\hline GIST-RX18 & 17 & 57 & $\mathrm{~F}$ & stomach & $\begin{array}{l}\text { liver } \\
\text { (M) }\end{array}$ & 148 & 125 & $\geq 1 / 3$ & high & yes & $\begin{array}{l}\text { KIT } \\
\text { exon } 11\end{array}$ & $\begin{array}{l}\text { I (145.9) } \\
\text { S (5.1) }\end{array}$ \\
\hline GIST-RX19 & 18 & 67 & M & stomach & $\begin{array}{l}\text { peritoneum } \\
\text { (M) }\end{array}$ & 59 & 50 & $<1 / 3$ & low & yes & $\begin{array}{l}\text { KIT } \\
\text { exon } 11\end{array}$ & $\begin{array}{l}\text { I (40.5) } \\
\text { S (18.7) }\end{array}$ \\
\hline GIST-RX20 & 19 & 64 & M & stomach & $\begin{array}{l}\text { peritoneum } \\
\text { (M) }\end{array}$ & 131 & 74 & $\geq 1 / 3$ & high & yes & $\begin{array}{l}\text { KIT } \\
\text { exon } 11\end{array}$ & \begin{tabular}{|l} 
I (29) \\
S (16.3) \\
R (32.9) \\
\end{tabular} \\
\hline GIST-RX21 & 20 & 55 & M & others & $\begin{array}{l}\text { liver } \\
(\mathrm{M})\end{array}$ & 163 & 51 & $\geq 1 / 3$ & high & yes & $\begin{array}{l}\text { cKIT } \\
\text { exon 11, } \\
P D G F R \\
\text { exon } 18 \\
\end{array}$ & $\begin{array}{l}\text { I (58.8), } \\
\text { S (18.1) } \\
\text { R }(32.9)\end{array}$ \\
\hline GIST-RX22 & 21 & 49 & M & $\begin{array}{l}\text { small } \\
\text { bowel }\end{array}$ & \begin{tabular}{|l|} 
liver \\
$(\mathrm{M})$
\end{tabular} & 64 & 65 & $\geq 1 / 3$ & high & yes & WT & $\begin{array}{l}\text { I (31.5) } \\
\text { S (4.1) }\end{array}$ \\
\hline GIST-RX23 & 22 & 63 & F & stomach & $\begin{array}{l}\text { peritoneum } \\
\text { (M) }\end{array}$ & 26 & 26 & $<1 / 3$ & low & no & $\begin{array}{l}\text { KIT } \\
\text { exon } 11\end{array}$ & $\mathrm{I}(72.2)$ \\
\hline GIST-X24 & 23 & 77 & F & stomach & \begin{tabular}{|l|} 
stomach \\
$(\mathrm{P})$
\end{tabular} & 150 & 37 & $\geq 1 / 3$ & high & yes & $\begin{array}{l}\text { KIT } \\
\text { exon } 11\end{array}$ & None \\
\hline GIST-RX25 & 24 & 50 & M & stomach & \begin{tabular}{|l|} 
stomach \\
$(\mathrm{P})$
\end{tabular} & 45 & 37 & $\geq 1 / 3$ & high & yes & $\begin{array}{l}\text { KIT } \\
\text { exon } 11\end{array}$ & I (5.8) \\
\hline GIST-RX26 & 25 & 69 & M & stomach & $\begin{array}{l}\text { liver } \\
(\mathrm{M})\end{array}$ & 76 & 123 & $\geq 1 / 3$ & high & no & $\begin{array}{l}\text { KIT } \\
\text { exon } 11\end{array}$ & \begin{tabular}{|l} 
I (19.5) \\
S (14.3)
\end{tabular} \\
\hline GIST-RX27 & 26 & 66 & F & others & $\begin{array}{l}\text { peritoneum } \\
\text { (M) }\end{array}$ & 62 & 16 & $<1 / 3$ & high & no & $\begin{array}{l}\text { KIT } \\
\text { exon } 9\end{array}$ & $\mathrm{I}(14.5)$ \\
\hline GIST-RX28 & 27 & 70 & M & stomach & $\begin{array}{l}\text { peritoneum } \\
\text { (M) }\end{array}$ & 20 & 320 & $\geq 1 / 3$ & high & yes & $\begin{array}{l}\text { KIT } \\
\text { exon } 11\end{array}$ & I ( $(24.6)$ \\
\hline GIST-RX29 & 16 & 52 & M & $\begin{array}{l}\text { small } \\
\text { bowel }\end{array}$ & $\begin{array}{l}\text { peritoneum } \\
\text { (M) }\end{array}$ & 80 & 97 & $\geq 1 / 3$ & high & yes & $\begin{array}{l}\text { KIT } \\
\text { exon } 11\end{array}$ & \begin{tabular}{|l|} 
I (56) \\
S (3.9) \\
R (3.7) \\
\end{tabular} \\
\hline GIST-RX30 & 28 & 71 & M & $\begin{array}{l}\text { small } \\
\text { bowel }\end{array}$ & \begin{tabular}{|l|} 
liver \\
$(\mathrm{M})$
\end{tabular} & 27 & 40 & $<1 / 3$ & high & no & $\begin{array}{l}\text { KIT } \\
\text { exon } 9\end{array}$ & I (91) \\
\hline GIST-RX31 & 29 & 81 & M & $\begin{array}{l}\text { small } \\
\text { bowel }\end{array}$ & $\begin{array}{l}\text { peritoneum } \\
\text { (M) }\end{array}$ & 82 & 36 & $\geq 1 / 3$ & high & yes & $\begin{array}{l}\text { KIT } \\
\text { exon } 11\end{array}$ & I (22.1) \\
\hline
\end{tabular}


Table 2. Characteristics of the GIST patients with successful PDX establishment. ${ }^{\mathrm{a} M}$, metastasis; P, primary tumor. ${ }^{b} I$, imatinib; $S$, sunitinib; $\mathrm{R}$, regorafenib; So, sorafenib. ${ }^{\mathrm{c}} K I T$ exon 11, PDGFR exon 18: The mutation analysis of $P D G F R$ was not performed at the time of diagnosis, so it was not possible to confirm whether it is a double mutation of KIT exon 11 and PDGFR exon 18. Mutations in KIT exon 11 and PDGFR exon 18 were both found at the time of resistance to imatinib and at the time of PDX establishment. WT, wild type.

previous report ${ }^{17}$; we are also monitoring the 28 models in terms of their responses to $\mathrm{TKI}^{17}$. The response of the PDX models to TKIs-specifically, the results of the imatinib responses-were consistent with the clinical resistance, although there were some differences in the response to TKIs among the TKI-resistant PDX models. We believe that our GIST PDX models may be useful for assessing the efficacy of new drugs in TKI-resistant GIST and for investigating the molecular and cellular mechanism of TKI resistance.

The success rate of PDX is affected by multiple factors. Shorter devascularized time from tumor resection to implantation in mice was shown as the main determinant for successful PDX engraftment ${ }^{18}$. However, another study reported that time to engraftment was not significantly related to successful engraftment ${ }^{19}$. Maintenance of tissues in cold and fresh media immediately after surgery, the size and number of implanted tissue, and the location of implantation may affect the success rate ${ }^{2}$. Stroma and endothelial cells, regulators of tumor growth, are also important ${ }^{20,21}$. Among the immunodeficient mouse strains used for PDX, the NSG mice are more suitable than other strains such as nude, severely compromised immune deficient (SCID), and nonobese diabetic (NOD)-SCID (NOD.CB17/Prkdcscid/J) ${ }^{22}$. The growth rates of patient tumors are highly variable ${ }^{23}$; similarly, the PDX models in our study exhibited varying growth rates with a median of 4.6 months (range, 1.5-11) for reaching $2 \mathrm{~cm}$ in diameter after implantation.

The aggressiveness and histological type of tumor as well as tumor cell proportion were considered important for successful PDX establishment ${ }^{2}$. Mitotic count, Ki-67, and cellularity are related to tumor cell proliferation and mitotic count itself is correlated closely with Ki-67 and cellularity ${ }^{24}$. High degrees of mitotic index, Ki-67 expression, and tumor cellularity were risk factors for the aggressive biological behavior of GISTs ${ }^{25,26}$. Therefore, factors related to malignant potentials seem to be associated with engraftment success. The presence of tumor necrosis was also correlated with a high risk for malignancy ${ }^{27}$. Patients who develop acquired resistance after TKI treatment are associated with aggressive clinical behavior ${ }^{28}$. As tumor size is associated with recurrence and resistance to TKIs in GIST ${ }^{29,30}$, a large-sized GIST can be related to rapid tumor progression and affect PDX engraftment success rate. A previous study has shown that metastatic tumors are more effective than primary tumors in yielding $\mathrm{PDX}^{19}$. Therefore, our results suggest that clinicopathologic factors associated with high risk for malignancy may influence the success of PDX engraftment.

KIT mutations are found in 60-85\% of GISTs, while PDGFRA exon 12, 14, and 18 mutations are found in $5-10 \%{ }^{31}$. Primary KIT mutations in GIST are found mostly in exon $11(61-71 \%)$, less in exon $9(7-15 \%)$, rarely in exons $17(0.5-1 \%)$ and $13(0.5-1.8 \%)$, and extremely rare in exon $8(0.15-0.23 \%)^{28}$. Resistance to TKIs and tumor progression are known to be influenced by genotypes. Generally, patients with primary KIT exon 11 mutant GISTs show better treatment outcomes with imatinib and regorafenib, in contrast to poor treatment outcomes with sunitinib ${ }^{28,32-34}$. Since our samples are all mixed up with tissues after imatinib, sunitinib, or regorafenib, the difference in success rate by genotype may not be statistically significant. KIT exon 11 mutations containing p.W557_K558 deletion were classified as high risk ${ }^{28}$. However, in our current study, these mutations were not significantly related to the PDX success rate. To date, there are no reports on GIST cell lines that harbor mutations in KIT exon 9. As for GIST PDX models, the GIST-RX4 model in our previous report ${ }^{17}$, UZLX-GIST2 ${ }^{15}$, and one commercially available model have KIT exon 9 mutations. In addition, two additional PDX models (GIST-RX27 and GIST-RX30) established in this study harbor mutations in KIT exon 9. As mutations in KIT exon 9 are rarer and more resistant to imatinib compared with mutations in KIT exon 11, its establishment as a PDX model holds critical research values.

In conclusion, we found that clinicopathologic factors such as after TKI treatment, large tumor size, high mitotic count, high Ki-67 index, high cellularity, presence of tumor necrosis, primary mutation in KIT exon 11, and metastatic tumor lesions were associated with a higher success rate of PDX establishment. Especially, Ki-67 index, after TKI treatment, and largest tumor size were notable factors for successful PDX engraftment. These findings may be helpful in assisting the establishment of PDX models from GISTs. Yet, additional studies are needed to improve the establishment of difficult-to-engraft GISTs such as those with deficiencies in succinate dehydrogenase.

\section{Materials and Methods}

Establishment of GIST PDX models. To establish patient-derived GIST xenografts, we implanted GIST tumor fragments from 185 samples of 176 Korean patients who underwent surgical resection prior to and after

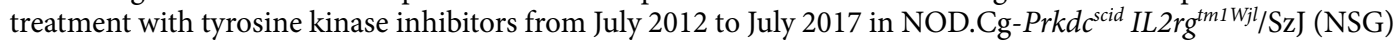
mice (Jackson Laboratory, Bar Harbor, ME, USA). Tumor and peripheral blood samples were collected from patients who provided written informed consent. This study was approved by the Institutional Review Board and the Institutional Animal Care and Use Committee of Asan Medical Center (Seoul, Korea, IRB No. 2017-13-266). All methods in this study were performed in accordance with the relevant guidelines and regulations.

Resected GIST lesions were immediately stored in a chilled medium, and the tumors were diced into 2 - to 3-mm pieces and subcutaneously transplanted into each hind side of the flank, especially near the axilla in 6- to 10 -weeks-old NSG mice ${ }^{17}$. After reaching $1.5-2 \mathrm{~cm}$ in long-axis diameter, the tumors were excised, cut into small pieces under sterile condition, and transplanted into successive BALB/c nude mice ${ }^{17}$. The PDXs were initially generated in F0 mice, then implanted in F1 mice. The established PDXs were passaged to generations greater than 


\begin{tabular}{|c|c|c|c|c|c|c|c|}
\hline \multirow[b]{2}{*}{ Variables } & \multicolumn{2}{|c|}{ Success $(\mathrm{N}=31)$} & \multicolumn{2}{|c|}{ Failure $(\mathrm{N}=164)$} & \multirow{2}{*}{\begin{tabular}{|l|} 
Univariate \\
$p$-value
\end{tabular}} & \multicolumn{2}{|l|}{ Multivariate } \\
\hline & $\mathbf{N}$ & $\%$ & $\mathbf{N}$ & $\%$ & & OR $(95 \% \mathrm{CI})$ & $p$-value \\
\hline Age & & & & & 0.870 & & \\
\hline$>59$ & 15 & 16.3 & 77 & 83.7 & & & \\
\hline$\leq 59$ & 16 & 17.2 & 77 & 82.8 & & & \\
\hline Sex & & & & & 0.279 & & \\
\hline female & 12 & 13.6 & 76 & 86.4 & & & \\
\hline male & 19 & 19.6 & 78 & 80.4 & & & \\
\hline Primary site & & & & & 0.534 & & \\
\hline stomach & 13 & 14.9 & 74 & 85.1 & & & \\
\hline others & 18 & 18.4 & 80 & 81.6 & & & \\
\hline Disease status & & & & & 0.003 & & 0.035 \\
\hline before TKI & 1 & 1.5 & 65 & 98.5 & & 1 & \\
\hline after TKI & 30 & 25.2 & 89 & 74.8 & & $9.437(1.730-176.100)$ & \\
\hline Largest tumor size $(\mathrm{mm})$ & & & & & $<0.001$ & & 0.057 \\
\hline$\leq 50$ & 6 & 6.5 & 87 & 93.5 & & 1 & \\
\hline $50-100$ & 13 & 21.7 & 47 & 78.3 & & $2.855(0.941-9.464)$ & 0.071 \\
\hline$>100$ & 12 & 37.5 & 20 & 62.5 & & 4.197 (1.285-14.835) & 0.020 \\
\hline Mitotic count (/50 HPFs) & & & & & $<0.001$ & & \\
\hline$\leq 5$ & 1 & 1.7 & 57 & 98.3 & & & \\
\hline$>5$ & 30 & 23.6 & 97 & 76.4 & & & \\
\hline Ki-67 & & & & & $<0.001$ & & $<0.001$ \\
\hline$<1 / 3$ & 7 & 5.4 & 122 & 94.6 & & 1 & \\
\hline$\geq 1 / 3$ & 24 & 42.9 & 32 & 57.1 & & $7.317(2.880-20.582)$ & \\
\hline Cellularity & & & & & $<0.001$ & & \\
\hline low & 4 & 4.9 & 78 & 95.1 & & & \\
\hline high & 27 & 26.2 & 76 & 73.8 & & & \\
\hline Tumor necrosis & & & & & 0.001 & & \\
\hline absent & 8 & 8.3 & 88 & 91.7 & & & \\
\hline present & 23 & 26.4 & 64 & 73.6 & & & \\
\hline $\mathrm{NE}$ & 0 & & 2 & & & & \\
\hline Cell type & & & & & 0.520 & & \\
\hline spindle & 18 & 14.8 & 104 & 85.2 & & & \\
\hline epithelioid & 4 & 19.0 & 17 & 81.0 & & & \\
\hline mixed & 9 & 22.5 & 31 & 77.5 & & & \\
\hline $\mathrm{NE}$ & 0 & & 2 & & & & \\
\hline Primary mutation & & & & & 0.031 & & \\
\hline others & 5 & 8.6 & 53 & 91.4 & & & \\
\hline KIT exon 11 & 26 & 22.4 & 90 & 77.6 & & & \\
\hline $\mathrm{NE}$ & 0 & & 11 & & & & \\
\hline Resection site for PDX & & & & & $<0.001$ & & \\
\hline primary & 4 & 4.6 & 83 & 95.4 & & & \\
\hline metastasis & 27 & 27.6 & 71 & 72.4 & & & \\
\hline
\end{tabular}

Table 3. Clinicopathological characteristics related to successful engraftment of GIST PDX. NE, not evaluated. Significant factors $(\mathrm{p}<0.05)$ from the univariate analysis were included in the multivariate analysis. Variable selections were performed by backward elimination.

F2. Pathologic diagnosis of the GISTs in the PDXs was assessed by a qualified pathologist and lymphomas were excluded to determine successful PDX.

Clinical information. We gathered the clinical information of the GIST patients including age, sex, resection site, disease status, largest tumor size on computed tomography scan, mitotic count, presence or absence of tumor necrosis, Ki-67, cellularity, cell type, primary mutation, and resection site of primary/metastatic tumor for PDX at the time of engraftment of PDX tumors.

Immunohistochemistry and hematoxylin-eosin staining. Formalin-fixed, paraffin-embedded, $4-\mu \mathrm{m}$ tumor sections were dewaxed in xylene, rehydrated with graded alcohol concentrations, and placed in an endogenous peroxide blocking buffer for 15 minutes ${ }^{17}$. Sections were washed in water, antigen-retrieved, and placed in citrate buffer ${ }^{17}$. Nonreactive staining was blocked by treating the sections with $1 \%$ horse serum in Tris-buffered saline (pH 6.0) for 3 minutes ${ }^{17}$. Ki-67 antibody (clone MIB1, IS626, 1:200; DAKO, Denmark) was 


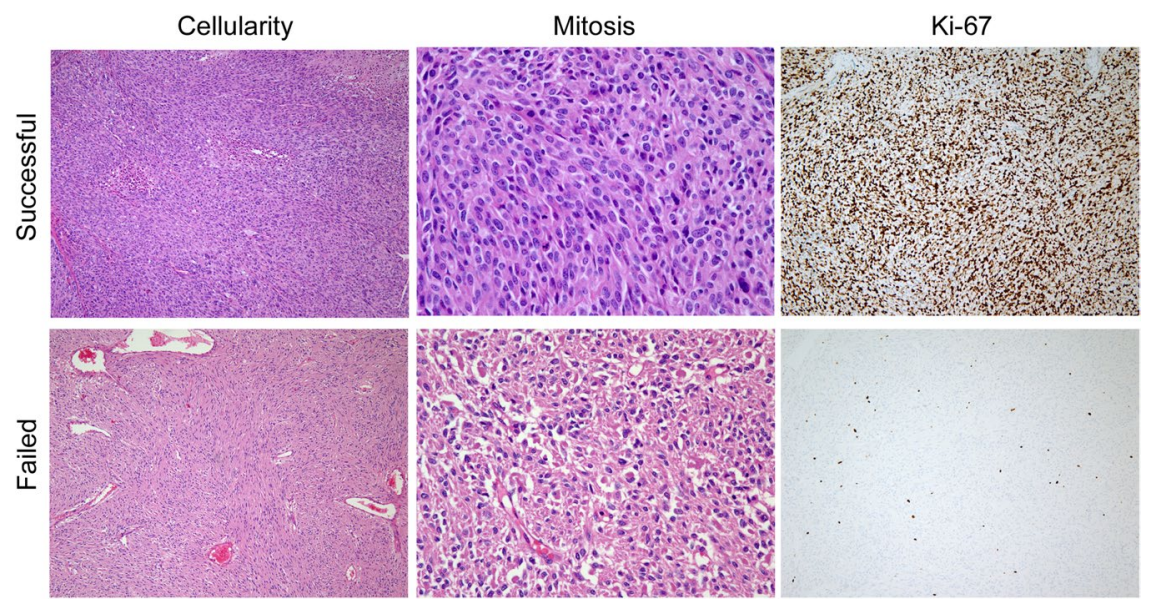

Figure 1. Representative photomicrographs of histomorphology and Ki-67 immunohistochemical staining. Upper row shows a successful case of PDX (RX18) and lower row shows a failed case. The first column denotes higher cellularity in a successful case (original magnification x100). In the second column, frequent mitotic figures are observed in the successful case but none in the failed case (original magnification, $\mathrm{x} 400$ ). The third column contrasts high versus low Ki-67 staining.

then applied and the binding of antibodies was detected using the avidin-biotin-peroxidase complex (Universal Elite ABC Kit; Vectastain, Burlingame, CA, USA) for 10 minutes. Diaminobenzidine tetrahydrochloride solution (Kit HK153-5K; Biogenex, San Ramon, CA, USA) was used as a chromogen ${ }^{17}$. The tumor specimens were stained with hematoxylin and eosin (H\&E) for the examination of the basic histomorphological features ${ }^{17}$.

Statistical analysis. All analyses were performed using SPSS version 23 (IBM Corp., Armonk, NY, USA) and $\mathrm{R}$ (version 3.6.1). $P$-values $<0.05$ were considered statistically significant. The Chi-squared test was used to compare categorical variables. Logistic regression analysis was performed to verify significant factors for successful PDX establishment. Factors that showed significant results from the univariate analysis were included in the multivariate analysis with backward elimination.

Received: 22 January 2020; Accepted: 15 April 2020;

Published online: 14 May 2020

\section{References}

1. Hidalgo, M. et al. Patient-derived xenograft models: an emerging platform for translational cancer research. Cancer Discov 4, 998-1013 (2014).

2. Jung, J., Seol, H. S. \& Chang, S. The Generation and Application of Patient-Derived Xenograft Model for Cancer Research. Cancer Res Treat 50, 1-10 (2018).

3. Garrido-Laguna, I. et al. Tumor engraftment in nude mice and enrichment in stroma- related gene pathways predict poor survival and resistance to gemcitabine in patients with pancreatic cancer. Clin Cancer Res 17, 5793-5800 (2011).

4. Keysar, S. B. et al. A patient tumor transplant model of squamous cell cancer identifies PI3K inhibitors as candidate therapeutics in defined molecular bins. Mol Oncol 7, 776-790 (2013).

5. Julien, S. et al. Characterization of a large panel of patient-derived tumor xenografts representing the clinical heterogeneity of human colorectal cancer. Clin Cancer Res 18, 5314-5328 (2012).

6. Kopetz, S., Lemos, R. \& Powis, G. The promise of patient-derived xenografts: the best laid plans of mice and men. Clin Cancer Res 18, 5160-5162 (2012).

7. Sulaiman, A. \& Wang, L. Bridging the divide: preclinical research discrepancies between triple-negative breast cancer cell lines and patient tumors. Oncotarget 8, 113269-113281 (2017).

8. Lu, W., Chao, T., Ruiqi, C., Juan, S. \& Zhihong, L. Patient-derived xenograft models in musculoskeletal malignancies. J Transl Med 16, 107 (2018).

9. Hirota, S. et al. Gain-of-function mutations of c-kit in human gastrointestinal stromal tumors. Science 279, 577-580 (1998).

10. Heinrich, M. C. et al. PDGFRA activating mutations in gastrointestinal stromal tumors. Science 299, 708-710 (2003).

11. Huynh, H. et al. Sorafenib induces growth suppression in mouse models of gastrointestinal stromal tumor. Mol Cancer Ther 8, $152-159$ (2009).

12. Revheim, M. E. et al. Establishment and characterization of a human gastrointestinal stromal tumour (GIST) xenograft in athymic nude mice. Anticancer Res 29, 4331-4336 (2009).

13. Van Looy, T. et al. Characterization and assessment of the sensitivity and resistance of a newly established human gastrointestinal stromal tumour xenograft model to treatment with tyrosine kinase inhibitors. Clin Sarcoma Res 4, 10 (2014).

14. Krishnan, V. G. et al. Whole-genome sequencing of asian lung cancers: second-hand smoke unlikely to be responsible for higher incidence of lung cancer among Asian never-smokers. Cancer Res 74, 6071-6081 (2014).

15. Van Looy, T. et al. Therapeutic Efficacy Assessment of CK6, a Monoclonal KIT Antibody, in a Panel of Gastrointestinal Stromal Tumor Xenograft Models. Transl Oncol 8, 112-118 (2015).

16. Sicklick, J. K. et al. Generation of orthotopic patient-derived xenografts from gastrointestinal stromal tumor. J Transl Med 12, 41 (2014).

17. Moya, C. \& Henrich, J. Culture-gene coevolutionary psychology: cultural learning, language, and ethnic psychology. Curr Opin Psychol 8, 112-118 (2016).

18. Choi, Y. Y. et al. Establishment and characterisation of patient-derived xenografts as paraclinical models for gastric cancer. Sci Rep 6, $22172(2016)$. 
19. Chijiwa, T. et al. Establishment of patient-derived cancer xenografts in immunodeficient NOG mice. Int J Oncol 47, 61-70 (2015).

20. Schneeberger, V. E., Allaj, V., Gardner, E. E., Poirier, J. T. \& Rudin, C. M. Quantitation of Murine Stroma and Selective Purification of the Human Tumor Component of Patient-Derived Xenografts for Genomic Analysis. PLoS One 11, e0160587 (2016).

21. Dong, Z. et al. Xenograft tumors vascularized with murine blood vessels may overestimate the effect of anti-tumor drugs: a pilot study. PLoS One 8, e84236 (2013).

22. Shultz, L. D. et al. Human lymphoid and myeloid cell development in NOD/LtSz-scid IL2R gamma null mice engrafted with mobilized human hemopoietic stem cells. J Immunol 174, 6477-6489 (2005).

23. Karamboulas, C. et al. Patient-Derived Xenografts for Prognostication and Personalized Treatment for Head and Neck Squamous Cell Carcinoma. Cell Rep 25(1318-1331), e1314 (2018).

24. Wang, X. et al. Helpful parameter for malignant potential of gastrointestinal stromal tumors (GIST). Jpn J Clin Oncol 32, 347-351 (2002).

25. Nakamura, N. et al. Prognostic significance of expressions of cell-cycle regulatory proteins in gastrointestinal stromal tumor and the relevance of the risk grade. Hum Pathol 36, 828-837 (2005).

26. $\mathrm{Wu}, \mathrm{T}$. J. et al. Surgical treatment and prognostic analysis for gastrointestinal stromal tumors (GISTs) of the small intestine: before the era of imatinib mesylate. BMC Gastroenterol 6, 29 (2006).

27. Khoo, J. J. \& Gunn, A. A clinical and immunohistochemical study of gastrointestinal stromal tumours. Malays J Pathol 27, 9-16 (2005).

28. Szucs, Z. et al. Molecular subtypes of gastrointestinal stromal tumors and their prognostic and therapeutic implications. Future Oncol 13, 93-107 (2017).

29. Fletcher, C. D. et al. Diagnosis of gastrointestinal stromal tumors: a consensus approach. Int J Surg Pathol 10, 81-89 (2002).

30. Van Glabbeke, M. et al. Initial and late resistance to imatinib in advanced gastrointestinal stromal tumors are predicted by different prognostic factors: a European Organisation for Research and Treatment of Cancer-Italian Sarcoma Group-Australasian Gastrointestinal Trials Group study. J Clin Oncol 23, 5795-5804 (2005).

31. Poveda, A. et al. GEIS guidelines for gastrointestinal sarcomas (GIST). Cancer Treat Rev 55, 107-119 (2017).

32. Reichardt, P. et al. Correlation of KIT and PDGFRA mutational status with clinical benefit in patients with gastrointestinal stromal tumor treated with sunitinib in a worldwide treatment-use trial. BMC Cancer 16, 22 (2016).

33. Heinrich, M. C. et al. Correlation of kinase genotype and clinical outcome in the North American Intergroup Phase III Trial of imatinib mesylate for treatment of advanced gastrointestinal stromal tumor: CALGB 150105 Study by Cancer and Leukemia Group B and Southwest Oncology Group. J Clin Oncol 26, 5360-5367 (2008).

34. Ben-Ami, E. et al. Long-term follow-up results of the multicenter phase II trial of regorafenib in patients with metastatic and/or unresectable GI stromal tumor after failure of standard tyrosine kinase inhibitor therapy. Ann Oncol 27, 1794-1799 (2016).

\section{Acknowledgements}

This study was supported by a grant (Number: HI14C0198) from the Korean Health Technology R\&D through the Korea Health Industry Development Institute (KHIDI), funded by the Ministry of Health and Welfare, Republic of Korea. We thank Dr. Joon Seo Lim from the Scientific Publications Team at Asan Medical Center for his editorial assistance in preparing this manuscript.

\section{Author contributions}

Conception and design: Y.-S. Na, M.-H. Ryu, Y.-K. Kang. Methodology: Y.-S. Na, M.-H. Ryu, Y.-S. Park, Y. Park, Y.-K. Kang. Acquisition of data: Y.-S. Na, M.-H. Ryu, Y.-S. Park, C.-W. Lee, J.-K. Lee, J.M. Park, J. Ma, Y.-K. Kang. Analysis and interpretation of data: Y.-S. Na, M.-H. Ryu, Y.-S. Park, Y.-K. Kang. Writing and editing of the manuscript: Y.-S. Na, M.-H. Ryu, Y.-K. Kang. Study supervision: Y.-K. Kang.

\section{Competing interests}

The authors declare no competing interests.

\section{Additional information}

Supplementary information is available for this paper at https://doi.org/10.1038/s41598-020-64552-w.

Correspondence and requests for materials should be addressed to Y.-K.K.

Reprints and permissions information is available at www.nature.com/reprints.

Publisher's note Springer Nature remains neutral with regard to jurisdictional claims in published maps and institutional affiliations

Open Access This article is licensed under a Creative Commons Attribution 4.0 International License, which permits use, sharing, adaptation, distribution and reproduction in any medium or format, as long as you give appropriate credit to the original author(s) and the source, provide a link to the Creative Commons license, and indicate if changes were made. The images or other third party material in this article are included in the article's Creative Commons license, unless indicated otherwise in a credit line to the material. If material is not included in the article's Creative Commons license and your intended use is not permitted by statutory regulation or exceeds the permitted use, you will need to obtain permission directly from the copyright holder. To view a copy of this license, visit http://creativecommons.org/licenses/by/4.0/.

(C) The Author(s) 2020 